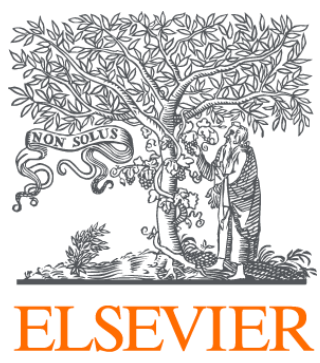

Since January 2020 Elsevier has created a COVID-19 resource centre with free information in English and Mandarin on the novel coronavirus COVID-

19. The COVID-19 resource centre is hosted on Elsevier Connect, the company's public news and information website.

Elsevier hereby grants permission to make all its COVID-19-related research that is available on the COVID-19 resource centre - including this research content - immediately available in PubMed Central and other publicly funded repositories, such as the WHO COVID database with rights for unrestricted research re-use and analyses in any form or by any means with acknowledgement of the original source. These permissions are granted for free by Elsevier for as long as the COVID-19 resource centre remains active. 


\title{
Lessons Learned During the COVID-19 Virus Pandemic
}

\author{
Antonio V Sterpetti, MD
}

Covid-19 is a new strain of coronavirus identified in China. Cases have now been detected in almost all countries in Asia, Australia, Europe, and North America. As of March 16, 2020, laboratories in Italy have diagnosed more than 27,000 people affected by the disease, with 2,158 deaths. Many infected patients do not have symptoms, so it is difficult to estimate the case fatality rate. In patients hospitalized for severe symptoms, the case fatality rate is around $15 \% \cdot{ }^{1-8}$ Elderly patients with severe comorbidities are at higher risk for mortality. Children and young adults rarely have symptoms, but they can carry the virus.

At this writing, Italy, for unknown reasons, has the highest prevalence of the disease, with mortality rates higher than in China and South Korea, probably related to the advanced mean age of the Italian population. So far, there has been a close correlation between regions with worse air pollution and diffusion of the virus in Italy. Italy has imposed severe restrictions to avoid diffusion of the virus. At the beginning, some inevitable organizational problems were encountered, which I would like to underline in this difficult moment, when the problems seem to be worsening in other countries.

\section{Need for ICU beds}

It is difficult to determine the percentage of contaminated patients, symptomatic or not, who will require hospitalization and intensive care. Ventilatory assistance is required in about $10 \%$ of the hospitalized patients, and the mortality rate in patients requiring ventilator assistance, younger than 75 years of age, without major comorbidity, is minimal. So, it is difficult to determine the number of ICU beds needed, but no country in the world, so far, has had enough ICU beds. This has been, and is, a major problem for Northern Italy.

\section{Disclosure Information: Nothing to disclose.}

Received March 17, 2020; Accepted March 18, 2020.

From the Department of Surgery, University of Rome Sapienza, Rome, Italy

Correspondence address: Antonio V Sterpetti, MD, Professore Aggregato, University of Rome La Sapienza, Istituto Pietro Valdoni, Viale Del Policlinico 100, Rome, Italy 00167. email: antonio.sterpetti@uniroma1.it

\section{Need for ICU doctors and nurses}

In Italy, doctors and nurses have done an extraordinary job, working more than 100 hours per week. There has been, and there is, a shortage of doctors and nurses. In Italy, many doctors and nurses were contaminated so they had to stop working. Again, it is difficult to determine the real prevalence of doctors and nurses who were contaminated. Covid-19 diagnosis should be performed in all nurses and doctors, because the disease often does not manifest in people younger than 35 years of age, and doctors and nurses can carry the disease all over the hospital.

\section{Need for hospital devoted only to Covid-19 patients}

The most common initial attitude in all countries has been an under-evaluation of the contamination rate. Often Covid-19 patients have been admitted through the emergency room to common wards, before a diagnosis was made, and they were isolated. In this period, the possibility of a diffuse contamination of the hospital workers is highly probable. The best solution is to have hospitals devoted only to Covid-19 patients, and to have emergency rooms in which patients with suspected Covid-19 infection are evaluated.

\section{Importance of avoiding medical facilities}

Too many medical facilities have been contaminated from the beginning, when patients with respiratory symptoms asked for advice. The best solution is to have dedicated and experienced people who, through e-mail and video conference, follow the patient. If symptoms get worse, then the patient can be taken by ambulance to the specialized emergency room, for complete evaluation. An initial shortage of masks, gloves, and other materials is inevitable.

\section{Telephone follow-up}

Many surgical patients are seen in outpatient clinic. Surgeons should be prepared to create a video conference network to follow their patients or to see new patients.

These are few of the main preventable problems I have seen in Italy. In this difficult situation, indications for surgery should be changed. Operations which can be 
deferred should be not performed, and the patient should not be admitted or seen in medical facilities.

\section{REFERENCES}

1. Paules C, Marston H, Fauci A. Coronavirus infections-more than just the common cold. JAMA January 23, 2020 [Epub ahead of print].

2. Wang C, Horby P, Hayden F, Gao G. A novel coronavirus outbreak of global health concern. The Lancet January 24, 2020 [Epub ahead of print].

3. Chan JF, Yuan S, Kok K, et al. A familial cluster of pneumonia associated with the 2019 novel coronavirus indicating personto-person transmission: a study of a family cluster. The Lancet January 24, 2020 [Epub ahead of print].
4. Huang C, Wang Y, Li X, et al. Clinical features of patients infected with 2019 novel coronavirus in Wuhan, China. The Lancet January 24, 2020 [Epub ahead of print].

5. Heymann D. Data sharing and outbreaks: best practice exemplified. The Lancet January 24, 2020 [Epub ahead of print].

6. Emerging understandings of 2019-nCoV. The Lancet January 24, 2020 [Epub ahead of print].

7. Chen N, Zhou M, Dong X, et al. Epidemiological and clinical characteristics of 99 cases of 2019 novel coronavirus pneumonia in Wuhan, China: a descriptive study. The Lancet January 29, 2020 [Epub ahead of print].

8. Lu R, Zhao X, Li J, et al. Genomic characterization and epidemiology of 2019 novel coronavirus: implications for virus origins and receptor binding. The Lancet January 29, 2020 [Epub ahead of print]. 